\title{
Water-soluble propolis and bee pollen of Trigona spp. from South Sulawesi Indonesia induce apoptosis in the human breast cancer MCF-7 cell line
}

\author{
ERI AMALIA, AJENG DIANTINI and ANAS SUBARNAS \\ Department of Pharmacology and Clinical Pharmacy, Faculty of Pharmacy, \\ Padjadjaran University, Sumedang, West Java 45363, Indonesia
}

Received April 3, 2020; Accepted August 19, 2020

DOI: $10.3892 / \mathrm{ol} .2020 .12137$

\begin{abstract}
Bee products are best known as one of the beneficial natural products providing multiple pharmacological effects, such as antimicrobial, antiviral, anti-inflammatory and anticancer effects. The present study aimed to identify potent products derived from the stingless bee Trigona spp. from Luwu Utara (South Sulawesi, Indonesia), focussing on the water-soluble extract of propolis and bee pollen, against the proliferation of the human breast cancer MCF-7 cell line. The results from DPPH (2,2-diphenyl-1-picrylhydrazyl) method of antioxidant assay revealed that water-soluble propolis and bee pollen had high antioxidant activity, with half-maximal effective concentrations against DPPH radicals of 1.3 and $0.4 \mathrm{mg} / \mathrm{ml}$, respectively. Additionally, water-soluble propolis and bee pollen exhibited a significant antiproliferative activity in MCF-7 cells, with $\mathrm{IC}_{50}$ values of $10.8 \pm 0.06$ and $18.6 \pm 0.03 \mathrm{mg} / \mathrm{ml}$, respectively $(\mathrm{P}<0.05)$. Significant cytotoxic effects were observed after $24 \mathrm{~h}$ of treatment via microscopic and flow cytometric analysis, where a morphological change toward late apoptosis was observed. By contrast, honey had low antioxidant activity and no antiproliferative effect in MCF-7 cells. The water-soluble propolis also exerted its antiproliferative effect in the human keratinocyte $\mathrm{HaCaT}$ cell line. The antiproliferative activity was similar $(\mathrm{P}>0.05)$ at 24 and $48 \mathrm{~h}$ of treatment, with $\mathrm{IC}_{50}$ at $2.7 \pm 0.06 \mathrm{mg} / \mathrm{ml}$ and $<0.4 \mathrm{mg} / \mathrm{ml}$, respectively. Notably, bee pollen was less toxic to HaCaT cells after $24 \mathrm{~h}$ of treatment than the water-soluble propolis, with $\mathrm{IC}_{50}>50 \mathrm{mg} / \mathrm{ml}$. Its antiproliferative activity was significantly
\end{abstract}

Correspondence to: Dr Eri Amalia or Dr Anas Subarnas, Department of Pharmacology and Clinical Pharmacy, Faculty of Pharmacy, Padjadjaran University, Laboratory Building 2, Bandung-Sumedang Road km 21, Jatinangor, Sumedang, West Java 45363, Indonesia

E-mail: amalia_eri@yahoo.co.id

E-mail: aasubarnas@yahoo.co.id

Key words: propolis, bee pollen, caffeic acid phenethyl ester, MCF-7, breast cancer, apoptosis increased after $48 \mathrm{~h}$ of treatment, with $\mathrm{IC}_{50}$ at $9.6 \pm 0.07 \mathrm{mg} / \mathrm{ml}$ $(\mathrm{P}<0.05)$. In addition, similar to other poplar propolis, the high-performance liquid chromatography-ultraviolet and electrospray ionisation mass spectrometry analyses revealed that caffeic acid phenethyl ester was not the main bioactive compound of the samples examined. Furthermore, two major proteins (between $\sim 50$ and $75 \mathrm{kDa}$ ) were identified in the water-soluble propolis and bee pollen. The present results suggested that water-soluble propolis and bee pollen may have the potential to be elaborated further as a breast anticancer therapy.

\section{Introduction}

The World Health Organization reported that 627,000 women died globally in 2018 due to breast cancer, and the rate of new cases of breast cancer is predicted to increase in future years (1). The risk of developing breast cancer involves genetic factors, such as alterations in BRCA1/BRCA2 and hormonal exposure history, as well as unhealthy lifestyle behaviours, such as smoking, drinking alcohol or the reduction of melatonin levels and impaired cortisol secretion, which occurs due to changes in the sleeping pattern of night shift workers $(2,3)$. Although there are $>30$ medicines available for breast cancer therapy, research into the potency of naturally-derived compounds remains vital, in order to pave the way for the discovery of novel drugs to use in breast cancer therapy (3).

A number of naturally-derived drugs, including paclitaxel and vincristine, have been applied in the clinical therapy of breast cancer (3-5). One of the natural resource products that is known as an anticancer therapy includes bee products (6-10). The bee products commonly consumed include honeycomb, honey, propolis, pollen, royal jelly and bee venom. Similar to other characteristics of natural products, the activity of each bee product depends on its bioactive constituents, which are affected by the species of the bee, the geographical origin of the beehive and the harvesting season of the products $(8,10)$.

The district of Luwu Utara, in the South Sulawesi province in Indonesia, is one of the most productive apiculture areas in Indonesia. The Trigona spp. is mainly cultivated to obtain high-quality honey as the primary valuable product, while the utilisation of its propolis and bee pollen is not as popular as 


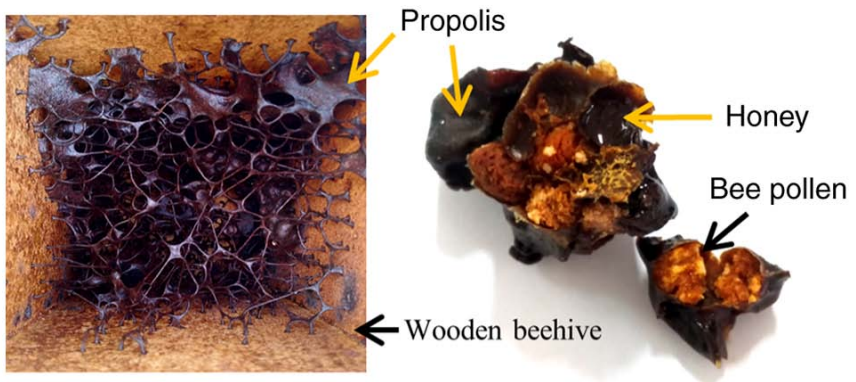

Figure 1. Products of stingless bees of the Trigona spp. (propolis, bee pollen and honey) collected from the district of Luwu Utara (South Sulawesi, Indonesia).

honey $(11,12)$. As shown in Fig. 1, propolis is a mixture of bee saliva with resinous material derived primarily from resins of leaf buds, sap flows and other plant sources, and is used as the main material to repair the beehive. The propolis of the Trigona spp. is known to have a strong aroma compared with other propolis produced in different Indonesian provinces (11). In contrast to propolis, bee pollen is a granular material derived from the pollen of various flowers, while honey results from a complex process involving the sugary material secretions of plants, followed by enzymatic reaction and water evaporation $(6,8)$.

In the research of propolis, numerous previous studies have utilised the ethanolic extract of propolis or another organic fraction $(6,7)$. However, the present study focused on the effect of the water-soluble fraction of propolis and bee pollen on the proliferation of the human breast cancer MCF-7 cell line. Human epithelial keratinocytes ( $\mathrm{HaCaT}$ ) were also used in the present study to estimate the toxicity of water-soluble propolis and bee pollen in normal cells.

Caffeic acid phenethyl ester (CAPE) is known as one of the bioactive compounds of propolis, mostly in the Baccharis propolis $(9,13)$. It has a mechanism of action to decrease the expression levels of NF- $\kappa \mathrm{B}$ in the apoptotic pathway of pancreatic and colon cancer (14). Another known mechanism of CAPE, as well as propolis, is to cause an accumulation of acetylated histone proteins in $\mathrm{MCF}-7$ estrogen receptor-positive $\left(\mathrm{ER}^{+}\right)$ cells, resulting in decreases in ER and progesterone receptor (PR) expression in these cells, thus, decreasing MCF-7 proliferation $(7,9,14)$. Therefore, the present study also aimed to identify the presence of CAPE in the examined products of the Trigona spp.

\section{Materials and methods}

Samples. Propolis and bee pollen were collected from a stingless bee of the Trigona spp. beehive in the district of Luwu Utara (South Sulawesi, Indonesia). These bee products were harvested from the same hive in September 2018. The products were stored at $2-8^{\circ} \mathrm{C}$ in a lid-closed plastic container until further use. CAPE with $>98 \%$ purity was purchased from Santa Cruz Biotechnology, Inc.

MCF-7 and HaCaT cell cultures. MCF-7 cells and HaCaT cells were provided by The Faculty of Medicine, Padjadjaran
University, Bandung-Indonesia. MCF-7 cells were cultured in DMEM and HaCaT cells were cultured in RPMI. Both cultures were supplemented with $10 \%$ FBS and $1 \%$ penicillin-streptomycin solution (all Gibco; Thermo Fisher Scientific, Inc.). The cells were cultured in T25 tissue culture flasks at $37^{\circ} \mathrm{C}$ in a $5 \% \mathrm{CO}_{2}$ incubator and were subcultured every 2-3 days before they reached confluency to keep the cultures healthy and actively growing. The experiments were performed with cells at 70-80\% confluence (15).

Preparation of water-soluble propolis and bee pollen. The water-soluble propolis was prepared by grinding $10 \mathrm{~g}$ propolis with the aid of an equivalent amount of $70 \%$ ethanol. This was transferred to a glass bottle containing $100 \mathrm{ml}$ of $70 \%$ ethanol. The bottle was protected from light and was left at room temperature for 4 days with intermittent shaking. On the 5 th day, the solvent was collected and $100 \mathrm{ml}$ fresh $70 \%$ ethanol was added to continue the extraction process for a further $24 \mathrm{~h}$ while shaking intermittently. This was repeated the next day. A total of $300 \mathrm{ml}$ solvent was collected after 7 days of extraction. The ethanol was removed using a rotary evaporator at $40-60^{\circ} \mathrm{C}$, at $40 \mathrm{rpm}$ and pressure of 200-250 bar (Rotavapor R-215; BÜCHI Labortechnik AG). Once the ethanol was completely removed, the wax-like water-insoluble formed and completely separated from the water-soluble fraction. The water-soluble propolis was freeze-dried in a Labconco freeze dryer (Thermo Fisher Scientific, Inc.) for $\sim 40-41 \mathrm{~h}$ in 5 cycles. The initial process was to decrease the temperature from room temperature to $-40^{\circ} \mathrm{C}$ for $\sim 5-6 \mathrm{~h}$. After reaching $-40^{\circ} \mathrm{C}$, the first cycle started by freezing at a constant of $-40^{\circ} \mathrm{C}$ for $\sim 18 \mathrm{~min}$. The subsequent cycles involved primary drying at $-34^{\circ} \mathrm{C}$ for $\sim 16 \mathrm{~h}$, first secondary drying at $-23^{\circ} \mathrm{C}$ for $\sim 6 \mathrm{~h}$, second secondary drying at $17^{\circ} \mathrm{C}$ for $\sim 8-9 \mathrm{~h}$ and final drying at $25^{\circ} \mathrm{C}$ for $\sim 4-5 \mathrm{~h}$. The freeze-dried water-soluble propolis was kept at $2-8^{\circ} \mathrm{C}$ until further use.

Bee pollen was prepared by dispersing it in water $1: 10(\mathrm{~b} / \mathrm{v})$ and filtered using Whatman ${ }^{\circledR}$ Grade 41 paper (Cytiva). The solution was freeze-dried for 40-41 h using the same protocol as the aforementioned preparation of water-soluble propolis and kept at $2-8^{\circ} \mathrm{C}$ until further use.

Identification of CAPE by high-performance liquid chromatography-ultraviolet (HPLC-UV) and electrospray ionisation mass spectrometry (ESI-MS). The HPLC-UV analysis was performed using a Prominence SIL-20A autosampler equipped with a Shimadzu LC-20AT pump (Shimadzu Corporation). Reverse-phase chromatography analyses were performed using a Shodex RSpak RP18 (Showa Denko America, Inc.), 4.6x $150 \mathrm{~mm}$ ID x length, $6 \mu \mathrm{m}$ particle size, $450 \AA$ pore size and $20 \mu \mathrm{l}$ volume injection. The mobile phase consisted of Solvent A [water: Formic acid (95:5)] and Solvent B (methanol). The linear gradient system was conducted at a flow rate of $1.0 \mathrm{ml} / \mathrm{min}$, starting from $30 \%$ Solvent B for $15 \mathrm{~min}$, increased to $40 \%$ Solvent B at $20 \mathrm{~min}, 45 \%$ Solvent B at $30 \mathrm{~min}, 60 \%$ Solvent B at $50 \mathrm{~min}, 80 \%$ Solvent B at $52 \mathrm{~min}$ and $80 \%$ Solvent B at $60 \mathrm{~min}$. The CAPE standard was prepared in methanol at $0.1 \mathrm{mg} / \mathrm{ml}$. Samples and standards solutions, as well as the mobile phase, were degassed and filtered through a $0.45-\mu \mathrm{m}$ membrane filter (EMD Millipore). The chromatogram was recorded at $340 \mathrm{~nm}$. Identification of the compounds 
was performed by comparing their retention time and UV absorption spectrum with those of the standards $(9,16)$.

The ESI-MS method was performed using the ACQUITY ${ }^{\circledR}$ triple quadrupole detector (Waters Corporation) using cone source start at $41 \mathrm{~V}$ in positive mode and $43 \mathrm{~V}$ in negative mode at capillary voltage $3.00 \mathrm{kV}$. The collision gas flow rate was set at 0.20 and $0.25 \mathrm{ml} / \mathrm{min}$ for positive and negative mode, respectively. The source and desolvation temperatures were 100 and $300^{\circ} \mathrm{C}$, respectively. Mass spectra of water-soluble propolis and bee pollen were further analysed in the negative ion mode scanning from 0 to $1,000 \mathrm{~m} / \mathrm{z}$. Data were analysed using the MassLynx ${ }^{\mathrm{TM}} 4.1$ software (Waters Corporation).

Protein identification via SDS-PAGE. A $12 \%$ polyacrylamide gel was used to identify the presence of proteins in the water-soluble propolis, bee pollen, honey and a commercial bee pollen powder (local company) as additional information. Raw bee pollen, honey and commercial bee pollen powder were dissolved in purified water to a concentration of $0.1 \mathrm{mg} / \mathrm{ml}$. The prior freeze-dried water-soluble propolis was used as a sample. A total of $50 \mu \mathrm{l}$ of each sample were mixed with SDS loading buffer $(0.756 \%$ Tris buffer $\mathrm{pH} 6.8$ containing $2 \%$ SDS, $20 \%$ bromophenol blue, $10 \%$ glycerol and $0.715 \mathrm{M}$ mercaptoethanol) and heated at $90^{\circ} \mathrm{C}$ for $5 \mathrm{~min}$. A total of $20 \mu \mathrm{l}$ of samples and $2 \mu \mathrm{l}$ of marker (Precision Plus Protein ${ }^{\mathrm{TM}}$ Dual colour standard; Bio-Rad Laboratories, Inc.) was loaded into each lane. Electrophoresis was performed using a Mini-Protean ${ }^{\circledR}$ Tetra Cell apparatus (Bio-Rad Laboratories, Inc.) at a constant voltage of $150 \mathrm{~V}$ for 45-60 min. The gel was then stained with Coomassie blue and the bands were observed visually and documented by gel imaging system (Azure Biosystems).

In vitro antioxidant activity assay using the 2,2-diphenyl-1-picrylhydrazyl (DPPH) radical scavenging assay. The radical scavenging activity (RSA) of the bee products was examined using the DPPH method. DPPH $(0.05 \mathrm{mM})$ was prepared by dissolving $10 \mathrm{mg}$ DPPH reagent (Sigma-Aldrich; Merck $\mathrm{KGaA})$ in $250 \mathrm{ml}$ acetonitrile: Methanol mixture $(1: 1, \mathrm{v} / \mathrm{v})$, followed by the addition of $250 \mathrm{ml}$ acetate buffer $(\mathrm{pH} \mathrm{5.5}$; $100 \mathrm{mM}$ ). Concentrations were prepared in water as follows: $76,152,227$ and $303 \mu \mathrm{g} / \mathrm{ml}$ of water-soluble propolis; 125, 250 and $500 \mu \mathrm{g} / \mathrm{ml}$ of bee pollen; and $3.75,7.5$ and $15 \mathrm{mg} / \mathrm{ml}$ of honey. A quantity of $0.077 \mathrm{ml}$ of the samples was added to $3 \mathrm{ml}$ DPPH solution and allowed to stand for 15-30 min in the dark at room temperature. The absorbance was measured at $\lambda_{\max }$ 515-517 nm, using 0.05 mM DPPH solution as a blank. The percentage of DPPH scavenging (\% RSA) was estimated using the following equation: $\% \mathrm{RSA}=\left[\left(\mathrm{A}_{0}-\mathrm{A}_{1}\right) / \mathrm{A}_{0}\right] \times 100$, where $\mathrm{A}_{0}$ is the absorbance of the initial DPPH solution as the blank and $A_{1}$ is the absorbance of the samples. The half-maximal effective concentration $\left(\mathrm{EC}_{50}\right)$ value was calculated using GraphPad Prism 7.05 software (GraphPad Software, Inc.).

In vitro antiproliferative assay in MCF-7 cells. The antiproliferative activity of water-soluble propolis and bee pollen was evaluated via MTT assay. The data was analysed in normalization method to negative control (without cells) and positive control (untreated cells). The dose-effect curves were analysed using GraphPad Prism 7.05 software in non-linear regression (sigmoidal) method. The antiproliferative activity of honey was also determined in this experiment as additional information. MCF-7 cells at a density of $2 \times 10^{4}$ cells/well were seeded in treated 96 -well plates and cultured for $24 \mathrm{~h}$ at $37^{\circ} \mathrm{C}$ with $5 \% \mathrm{CO}_{2}$ to let the cells adhere to the bottom of the plates. The cultures were then treated with different concentrations $(0.7,1.3,2.7,5.3,10.7,21.4$ and $42.7 \mathrm{mg} / \mathrm{ml}$ of water-soluble propolis, and $0.8,1.7,3.3,6.6,13.3,26.5$ and $53 \mathrm{mg} / \mathrm{ml}$ of bee pollen), and cultured for $24 \mathrm{~h}$ at $37^{\circ} \mathrm{C}$ with $5 \% \mathrm{CO}_{2}$. Each concentration was tested in triplicate, and untreated cells were used as the positive control and a well without cells as the negative control. After $24 \mathrm{~h}$ of incubation, the medium was aspirated and replaced with $100 \mu \mathrm{l}$ of freshly prepared medium containing $0.5 \mathrm{mg} / \mathrm{ml}$ MTT reagent, followed by further 3-4 h incubation at $37^{\circ} \mathrm{C}$ with $5 \% \mathrm{CO}_{2}$. The MTT solution was removed from the well and $100 \mu \mathrm{l}$ DMSO was added in each well to solubilise the formazan crystals. Finally, the absorbance was measured at a wavelength of $450 \mathrm{~nm}$ using the Multiscan ${ }^{\circledR}$ Ex multiplate reader (Thermo Labsystems).

In vitro antiproliferative assay in HaCaT cells. The antiproliferative activity of water-soluble propolis and bee pollen in $\mathrm{HaCaT}$ cells was evaluated via MTT assay similar to in vitro antiproliferative assay in MCF-7; however, cells were used at the density of $5 \times 10^{3}$ cells/well. The cultures were treated with water-soluble propolis and bee pollen at concentrations of 0.4 , $0.8,1.6,3.1,6.3,12.5$ and $25 \mathrm{mg} / \mathrm{ml}$, and cultured for 24 or $48 \mathrm{~h}$ at $37^{\circ} \mathrm{C}$ with $5 \% \mathrm{CO}_{2}$, in order to observed the effect of different treatments over time.

Flow cytometric analysis. MCF-7 cells were seeded in a 6-well plate at a density of $5 \times 10^{5}$ cells/well and were cultured for $24 \mathrm{~h}$ at $37^{\circ} \mathrm{C}$ with $5 \% \mathrm{CO}_{2}$. The cultures were treated with $10.8 \mathrm{mg} / \mathrm{ml}$ water-soluble propolis and $18.6 \mathrm{mg} / \mathrm{ml}$ bee pollen, and incubated for $24 \mathrm{~h}$ at $37^{\circ} \mathrm{C}$ with $5 \% \mathrm{CO}_{2}$. After $24 \mathrm{~h}$ of treatment, cells were observed by inverted phase contrast microscope (Olympus Corporation) at x100 and x200 magnifications. The cells were harvested using $0.01 \%$ trypsin at $37^{\circ} \mathrm{C}$ for $5 \mathrm{~min}$. The cells were collected in 2-ml tubes and were washed twice with cold PBS via centrifugation for $5 \mathrm{~min}$ at $300 \mathrm{x}$ g at room temperature. The cells were gently resuspended in $1 \mathrm{X}$ binding buffer at a concentration of $1 \times 10^{6}$ cells $/ \mathrm{ml}$. Further analysis was performed using the FITC-Annexin V apoptosis detection kit I (BD Pharmingen; BD Biosciences), according to the manufacturer's protocol. Briefly, $100 \mu \mathrm{l}$ of the samples solution $\left(1 \times 10^{5}\right.$ cells $\left./ \mathrm{ml}\right)$ was transferred to a $5-\mathrm{ml}$ culture tube. A total of $5 \mu \mathrm{l}$ FITC-Annexin $\mathrm{V}$ and $5 \mu \mathrm{l}$ PI was added to the tube for $15 \mathrm{~min}$ in the dark at room temperature. Finally, $400 \mu \mathrm{l}$ $1 \mathrm{X}$ binding buffer was added to the tubes. The samples were analysed immediately within $1 \mathrm{~h}$ by using flow cytometer (BD Accuri $^{\mathrm{TM}}$ C6 instrument; BD Biosciences) and were analysed by using BD Accuri ${ }^{\mathrm{TM}}$ C6 software (version 1.0.264.21; BD Biosciences).

Statistical analysis. The in vitro experiments to measure the antioxidant and antiproliferative activities in MCF-7 and $\mathrm{HaCaT}$ cells were performed in triplicate $(n=3)$ and repeated in three independent experiments. The data were represented as the means \pm standard deviation. The antioxidant activity assay was analysed by GraphPad Prism 7.05 software. The 


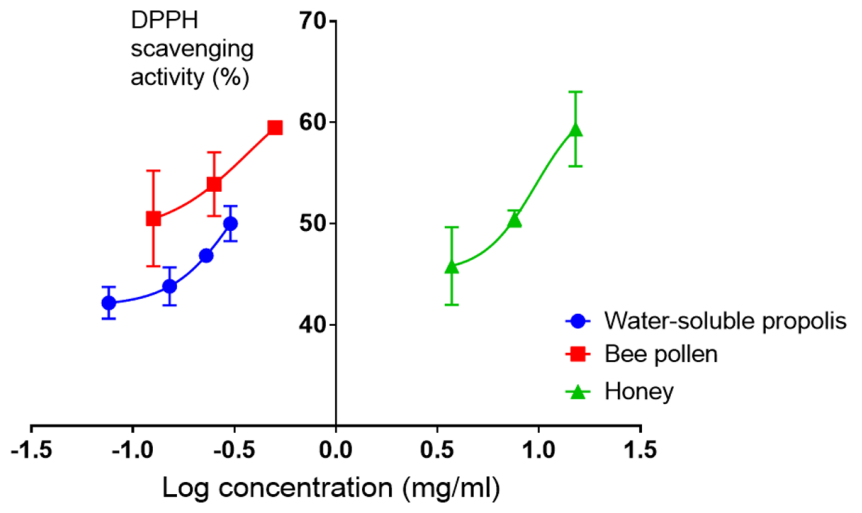

Figure 2. Antioxidant activity of propolis, bee pollen and honey. Bee pollen exhibited the highest antioxidant activity with $\mathrm{EC}_{50} 0.394 \pm 0.067 \mathrm{mg} / \mathrm{ml}$, while water-soluble propolis and honey had $\mathrm{EC}_{50}$ values of $1.273 \pm 0.399$ and $6.173 \pm 0.579 \mathrm{mg} / \mathrm{ml}$, respectively. DPPH, 2,2-diphenyl-1-picrylhydrazyl.

in vitro antiproliferative assays in MCF-7 cells was analysed by GraphPad Prism 7.05 software for the $\mathrm{IC}_{50}$ determination, followed by one-way ANOVA by SPSS v23.0 (IBM Corp.). The in vitro antiproliferative assay in $\mathrm{HaCaT}$ cells was analysed by GraphPad Prism 7.05 software, followed by two-way ANOVA and Tukey's post hoc test by SPSS v23.0 (IBM Corp). The flow cytometric results were analysed by one-way ANOVA followed by Tukey's post hoc test by SPSS v23.0. $\mathrm{P}<0.05$ was considered to indicate a statistically significant difference.

\section{Results}

Preparation of water-soluble propolis and bee pollen. The freeze-dried water-soluble propolis and bee pollen formed a solid, hard, flake-like material at $2-8^{\circ} \mathrm{C}$. These samples were easily dissolved in water and medium. They must be stored at $2-8^{\circ} \mathrm{C}$, as storing at room temperature for $>8 \mathrm{~h}$ will melt the flake-like material into a sticky viscous material.

Total antioxidant properties. The antioxidant activity analysis revealed that the half-maximal effective concentration $\left(\mathrm{EC}_{50}\right)$ values against DPPH radicals of water-soluble propolis and bee pollen were $1.3 \pm 0.4$ and $0.4 \pm 0.07 \mathrm{mg} / \mathrm{ml}$, respectively, while the $\mathrm{EC}_{50}$ of honey was $6.2 \pm 0.6 \mathrm{mg} / \mathrm{ml}$. This indicated that the antioxidant activity of bee pollen was 3 times higher than that of water-soluble propolis and 15 times higher than that of honey (Fig. 2).

Identification of CAPE via HPLC-UV and ESI-MS. The HPLC-UV analysis was performed to identify the presence of CAPE in water-soluble propolis and bee pollen, as well as in honey and raw propolis. However, the present study revealed that honey and bee pollen of the Trigona spp. did not contain CAPE, as no peak of CAPE was identified in its chromatogram. Meanwhile, peak of CAPE was identified only in trace values in raw propolis, as well as in water-soluble propolis, estimated as $2 \mathrm{ppb}$. Further analysis was conducted using ESI-MS in source positive ion and negative ion spectra to confirm the reason for the absence or traces result in the HPLC-UV analysis. As shown in Fig. 3, the source negative ion spectra of CAPE $\left(\mathrm{C}_{17} \mathrm{H}_{16} \mathrm{O}_{4}\right)$, which has a molecular weight of $284.3 \mathrm{~g} / \mathrm{mol}$, was not identified as a major bioactive constituent in water-soluble propolis nor in bee pollen. The weak spectrum of CAPE was identified in bee pollen with $\mathrm{m} / \mathrm{z}$ 283.45. Mass spectra of water-soluble propolis in the negative ion mode scanning from 0 to $1,000 \mathrm{~m} / \mathrm{z}$ exhibited similar major compounds to bee pollen, having a spectrum with $\mathrm{m} / \mathrm{z}$ 195.26[M-H]-, 255.46[M-H]-, 279.5[M-H] and $339.38[\mathrm{M}-\mathrm{H}]-$. Meanwhile, the mass spectra of bee pollen acquired using electrospray in the negative ion mode scanning from 0 to $1,000 \mathrm{~m} / \mathrm{z}$ exhibited several major compounds having a spectrum with $\mathrm{m} / \mathrm{z} 195.26[\mathrm{M}-\mathrm{H}]-, 339.46[\mathrm{M}-\mathrm{H}]-$ and 431.36[M-H]. The major constituent was assumed to be flavonoids. However, further experiments are required to identify the major constituents in these natural products as observed in the ESI-MS spectra.

Protein identification via SDS-PAGE. The present study examined the presence of protein primarily in water-soluble propolis and bee pollen, as well as in honey, in the insoluble part of propolis (wax fraction), which was collected during the preparation of the water-soluble propolis, and in commercial bee pollen powder. As shown in Fig. 4, no protein bands appeared in the lanes of honey, the wax fraction of propolis and the commercial bee pollen powder. Notably, protein bands were observed in the lane of bee pollen and water-soluble propolis. Two major bands were identified with a size between 50 and $75 \mathrm{kDa}$. Further studies are required to evaluate the characteristics of proteins or enzymes present in bee pollen and water-soluble protein.

In vitro antiproliferative assay in MCF-7 cells. The MTT assay revealed that water-soluble propolis and bee pollen induced inhibitory effects against MCF-7 cell proliferation in a concentration-dependent manner after $24 \mathrm{~h}$ of treatment. The samples exhibited significant activity $(\mathrm{P}<0.05)$ with $\mathrm{IC}_{50}$ values of $10.8 \pm 0.06$ and $18.6 \pm 0.03 \mathrm{mg} / \mathrm{ml}$, respectively (Fig. 5). Furthermore, honey did not exhibit any cytotoxic activity against MCF-7 cell proliferation after $24 \mathrm{~h}$ (data not shown).

In vitro antiproliferative assay in HaCaT cells. The experiment revealed that $\mathrm{HaCaT}$ cell treatment with water-soluble propolis for $24 \mathrm{~h}$ giving $\mathrm{IC}_{50}$ of $2.7 \pm 0.06 \mathrm{mg} / \mathrm{ml}$. The cytotoxic effect was higher after $48 \mathrm{~h}$ of treatment than $24 \mathrm{~h}$, with an $\mathrm{IC}_{50}$ of $<0.4 \mathrm{mg} / \mathrm{ml}$. Fig. 6 shows that there were significant differences at concentrations of $0.4(\mathrm{P}<0.0001), 0.8(\mathrm{P}<0.001)$, $1.6(\mathrm{P}<0.01)$ and $25 \mathrm{mg} / \mathrm{ml}(\mathrm{P}<0.05)$. Nevertheless, the two-way ANOVA with Tukey's post hoc test revealed that there was no significant difference between the treatment with water-soluble propolis at 24 and $48 \mathrm{~h}(\mathrm{P}>0.05)$ at concentrations of $3.1,6.3$ and $12.5 \mathrm{mg} / \mathrm{ml}$. By contrast, the treatment of cells with bee pollen for $24 \mathrm{~h}$ indicated that bee pollen was less toxic to the cells compared with water-soluble propolis at concentration $<25 \mathrm{mg} / \mathrm{ml}$ with an $\mathrm{IC}_{50}>50 \mathrm{mg} / \mathrm{ml}$ (estimated as $\sim 975.2 \mathrm{mg} / \mathrm{ml}$ using GraphPad Prism 7.05 software). The antiproliferative activity increased after $48 \mathrm{~h}$ of treatment at higher concentrations, with an $\mathrm{IC}_{50}$ of $9.6 \pm 0.07 \mathrm{mg} / \mathrm{ml}$.

Furthermore, the antiproliferative activities of the samples were observed at 24 and $48 \mathrm{~h}$. Regarding the $\mathrm{IC}_{50}$ values resulting from each treatment, there were significant differences in antiproliverative activity between water-soluble 
A

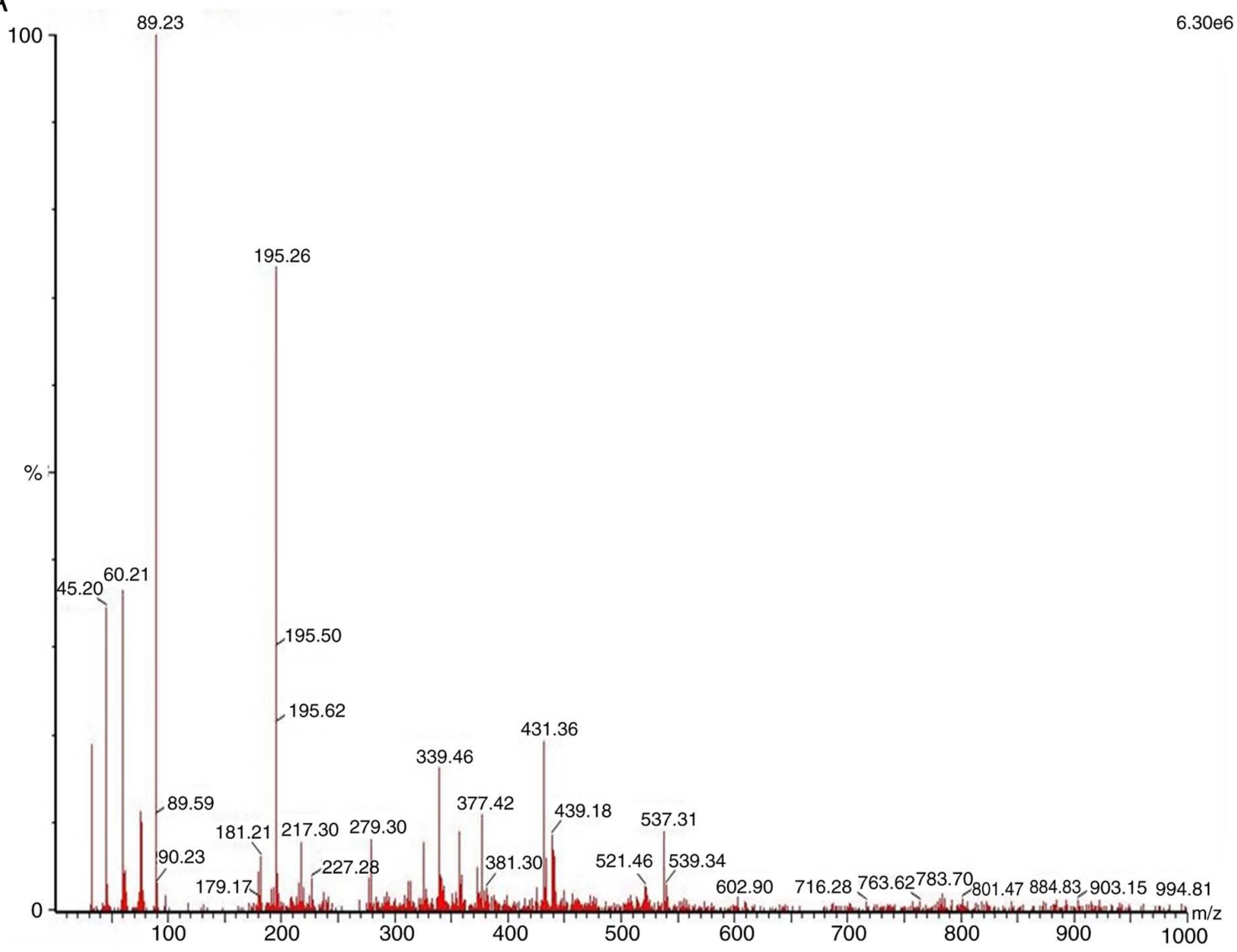

B

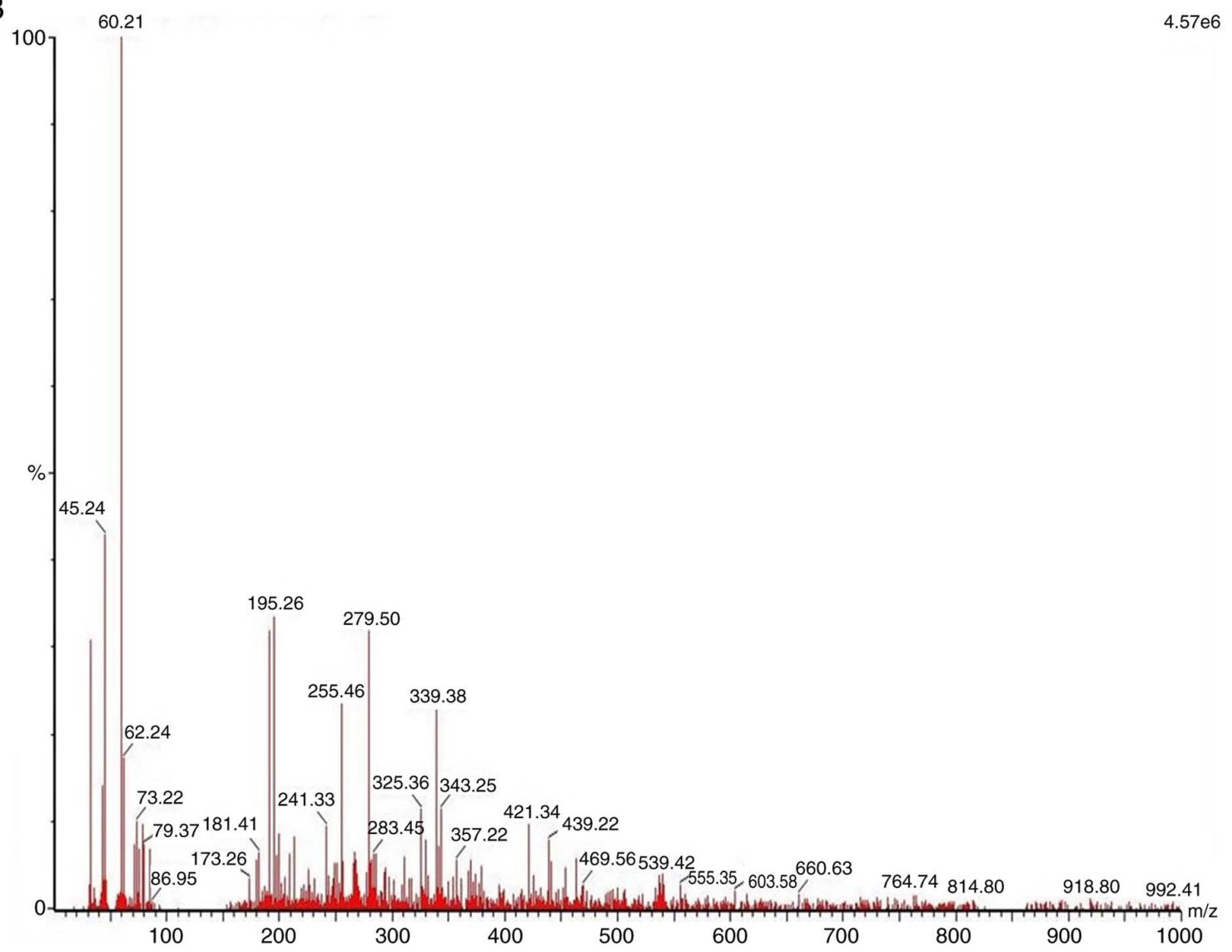

Figure 3. Electrospray ionization-mass spectrometry spectra of (A) bee pollen and (B) water-soluble propolis in source negative ion. Caffeic acid phenethyl ester (molecular weight 284.31) spectra was not identified as the main bioactive constituent in these products. 


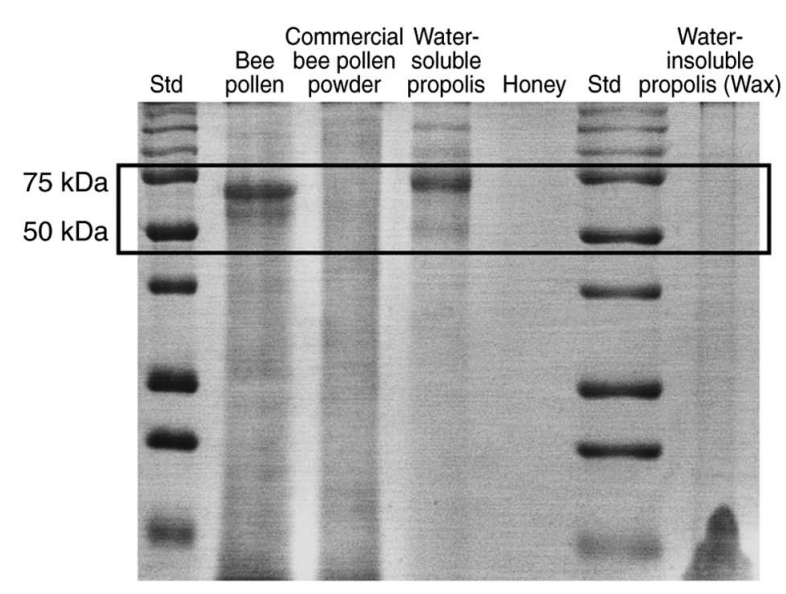

Figure 4. Protein identification of bee products. Two major bands (between 50 and $75 \mathrm{kDa}$ ) were identified in bee pollen and water-soluble propolis.

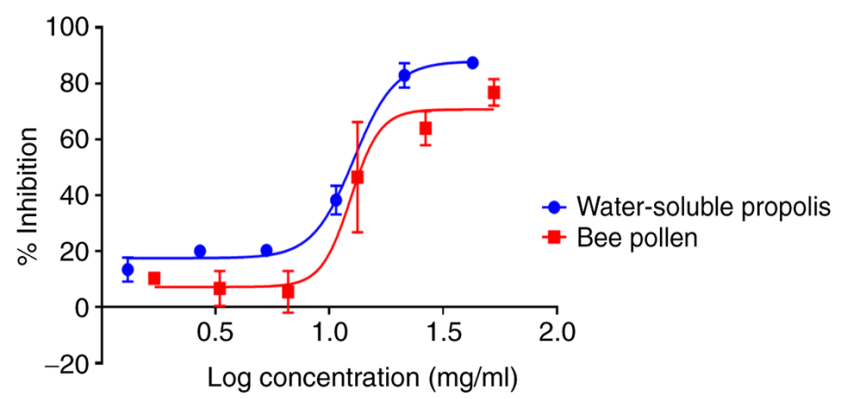

Figure 5. Antiproliferative activity of water-soluble propolis and bee pollen in the breast cancer MCF-7 cell line after $24 \mathrm{~h}$ of treatment. The samples exhibited an $\mathrm{IC}_{50}$ of $10.8 \pm 0.06$ and $18.6 \pm 0.03 \mathrm{mg} / \mathrm{ml}$, respectively. $\mathrm{P}<0.05$ between $\mathrm{IC}_{50}$ value of water-soluble propolis and bee pollen.

propolis and bee pollen at $24 \mathrm{~h}(\mathrm{P}<0.05)$ and $48 \mathrm{~h}(\mathrm{P}<0.05)$. The results from Fig. 6 revealed that there were significant differences between treatment with water-soluble propolis and bee pollen at $24 \mathrm{~h}$ using concentrations $0.4,0.8,1.6,3.1,6.3$, 12.5 and $25 \mathrm{mg} / \mathrm{ml}(\mathrm{P}<0.0001)$. Significant differences were also observed between treatment with water-soluble propolis and bee pollen at $48 \mathrm{~h}$ using concentrations $0.4,0.8,1.6,3.1,6.3$ and $12.5 \mathrm{mg} / \mathrm{ml}(\mathrm{P}<0.0001)$. Interestingly, a higher dose of bee pollen $(25 \mathrm{mg} / \mathrm{ml})$ resulted in significant difference $(\mathrm{P}<0.05)$ compared with water-soluble propolis at the same concentration of $25 \mathrm{mg} / \mathrm{ml}$. The result revealed that the antiproliferative activity of bee pollen increased in a time- and dose-dependent manner.

Flow cytometric analysis. Flow cytometric analysis results were reported as the percentage of live, necrotic or apoptotic cells (early or late apoptosis). Fig. 7A represents a summary of the flow cytometric analysis as a bar chart, exhibiting a decrease of live cells and an increased proportion of apoptotic cells after treatment with water-soluble propolis and bee pollen compared with in the untreated cells used as a control. Untreated MCF-7 cells represented a normal cell population, where most cells $(88.0 \%)$ were live cells and small proportions of cells were in early apoptosis, late apoptosis or necrosis $(0.2$, 9.5 and $2.3 \%$, respectively; Fig. 7B). MCF-7 cells treated with water-soluble propolis at the $\mathrm{IC}_{50}$ concentration $(10.8 \mathrm{mg} / \mathrm{ml})$

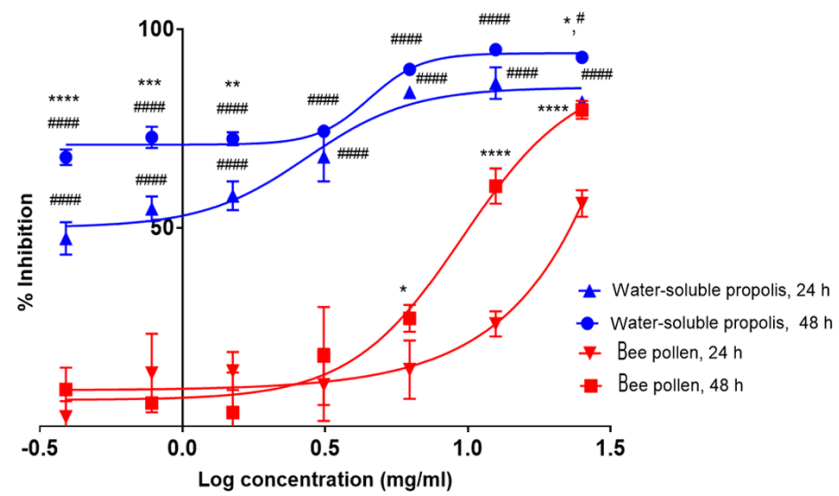

Figure 6. Antiproliferative activity of water-soluble propolis and bee pollen in the $\mathrm{HaCaT}$ cell line after 24 and $48 \mathrm{~h}$ of treatment in different doses presented as the means \pm standard deviation from 3 biological replicates. A two-way ANOVA with Tukey's post-hoc test was performed using GraphPad Prism 7.05 software, by performing multiple comparisons to assess the antiproliferative activity at a specific dose in each group. ${ }^{*} \mathrm{P}<0.05,{ }^{* *} \mathrm{P}<0.01$, ${ }^{* * *} \mathrm{P}<0.001$ and ${ }^{* * * *} \mathrm{P}<0.0001$ vs. $24 \mathrm{~h}$ of the same treatment (water-soluble propolis or bee pollen) and same concentration. ${ }^{\#} \mathrm{P}<0.05$ and ${ }^{\# \# \#} \mathrm{P}<0.0001$ vs. treatment with bee pollen at the same time point and same concentration.

for 24 h exhibited a significant decrease in live cells $(\mathrm{P}<0.001$; Fig. 7A). Flow cytometric analysis revealed that the percentages of live cells and late apoptotic cells were 8.2 and $89.8 \%$, respectively, while cells in early apoptosis and necrosis were 0.8 and $1.2 \%$, respectively (Fig. 7C). In the present study, MCF-7 cells treated with bee pollen at $\mathrm{IC}_{50}$ concentration of $18.6 \mathrm{mg} / \mathrm{ml}$, for $24 \mathrm{~h}$ exhibited a notable result where a progression of cells towards late apoptosis. Flow cytometric analysis of the sample treated with bee pollen revealed that the percentage of live cells was $78.8 \%$, and necrotic cells represented $0.8 \%$ of the cell population. Compared with untreated cells, the percentages of early and late apoptotic cells increased to 3.5 and $16.9 \%$, respectively. (Fig. 7D). Observation of the MCF-7 cell culture after $24 \mathrm{~h}$ of treatment by inverted phase contrast microscope at $\mathrm{x} 100$ and $\mathrm{x} 200$ magnification showed results similar to the flow cytometric analysis. The results from the present study demonstrated that MCF-7 cell treatment with water-soluble propolis and bee pollen lead to decreased cell density (Fig. 8C and D). Furthermore, untreated cells showed normal proliferation and reached confluency in $24 \mathrm{~h}$ (Fig. 8A). As presented in Fig. 8B, untreated MCF-7 cells, which grew as normal and healthy cells, had a cobblestone-like phenotype with 25-30 $\mu \mathrm{m}$ length. However, MCF-7 cells treated with bee pollen presented with early apoptosis according to cell shrinkage to rounded cells (Fig. 8D). Treatment of MCF-7 cells with water-soluble propolis resulted in cells in late apoptosis, where blebbing cells, formation of apoptopodia and apoptotic bodies were observed (Fig. 8C).

\section{Discussion}

A number of natural products have been used as traditional medicines to maintain the quality of life and to contribute to the development of novel drugs. Natural product-derived drug discoveries have demonstrated their pharmacological activity, for example as cardiovascular (digoxin obtained from Digitalis purpurea), anti-malaria (quinine from Cinchona officinalis) and antineoplastic agents (paclitaxel derived from 
A
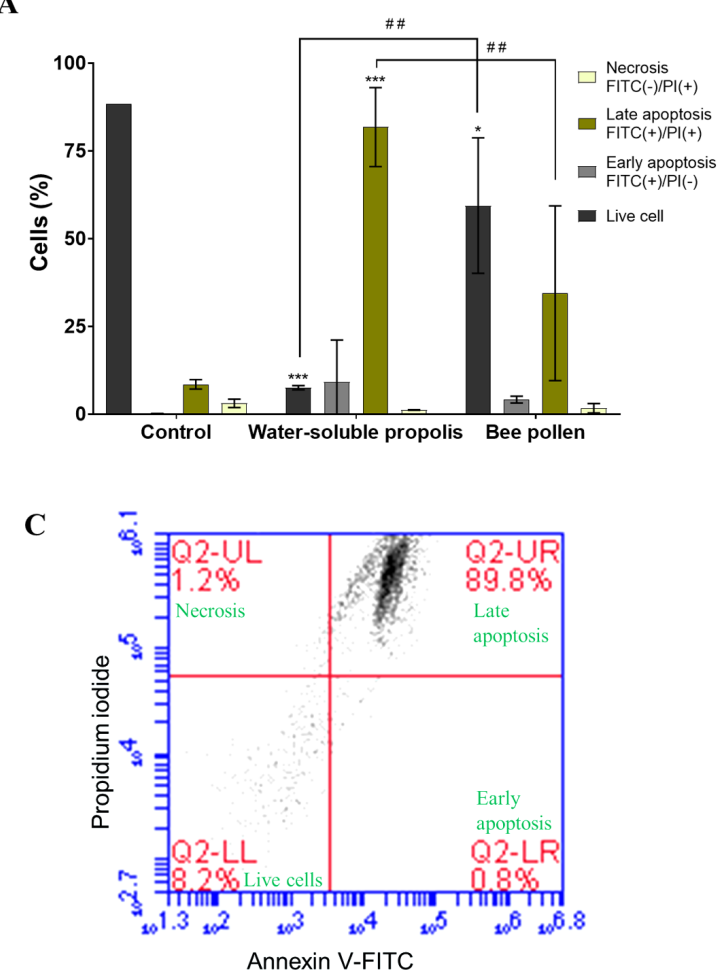

B

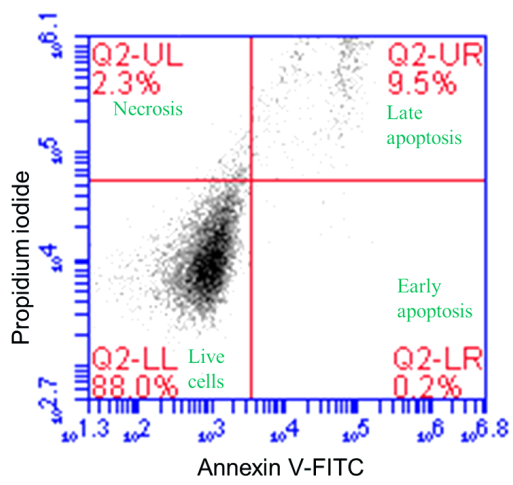

D

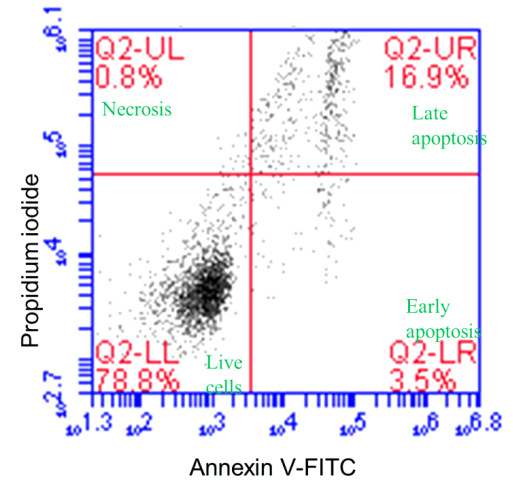

Figure 7. (A) Bar chart displaying a decrease of live cells and an increased proportion of apoptotic cells after treatment with water-soluble propolis and bee pollen compared with untreated cells used as a control. Bar graph represents the percentages of cells in different stages (live, early apoptotic, late apoptotic and necrotic cells). The data are presented as the mean \pm SD $(n=3)$. One-way ANOVA with Tukey's post hoc test was performed for each stage using SPSS. ${ }^{*} \mathrm{P}<0.05$ and ${ }^{* * *} \mathrm{P}<0.001$ vs. control group. ${ }^{\# \#} \mathrm{P}<0.01$ vs. water-soluble propolis. Representative flow cytometric plots of $(\mathrm{B})$ untreated $\mathrm{MCF}-7$ cells, $(\mathrm{C}) \mathrm{MCF}-7$ cells treated with water-soluble propolis and (D) MCF-7 cells treated with bee pollen.

A
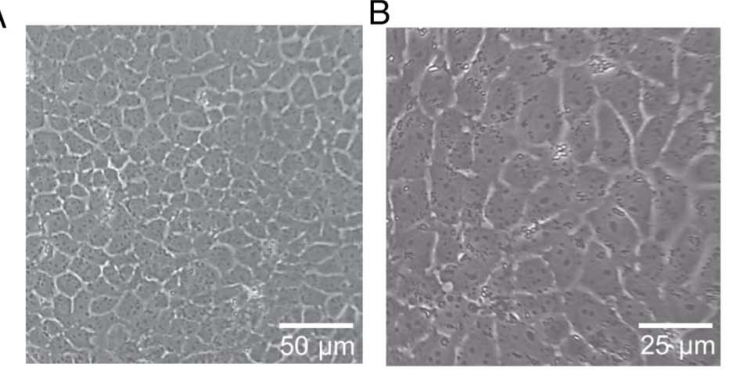

C

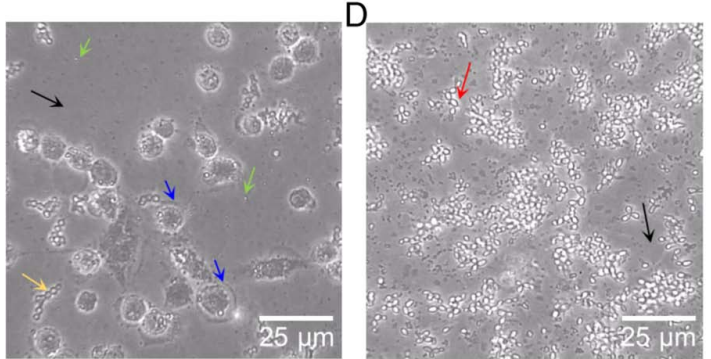

Figure 8. Morphological analysis of MCF-7 cells following treatment with water-soluble propolis and bee pollen. Inverted microscopy of untreated MCF-7 cells observed at a magnification of (A) x100 (scale bar, $50 \mu \mathrm{m}$ ) and (B) x200 (scale bar, $25 \mu \mathrm{m}$ ) showed normal confluency after $24 \mathrm{~h}$ of incubation. The black spots observed in healthy cells are debris derived from dead cells as occurs in the normal cell cycle. Cells treated with (C) $10.8 \mathrm{mg} / \mathrm{ml}$ water-soluble propolis and (D) $18.6 \mathrm{mg} / \mathrm{ml}$ bee pollen for $24 \mathrm{~h}$ at their $\mathrm{IC}_{50}$ values exhibited a decrease in cell density as indicated by black arrows. The red arrow indicates shrunken and rounded cells. The blue arrows indicate suspended cells with apoptotic blebbing. The yellow and green arrows indicate cell fragmentation in late apoptosis via the formation of beaded apoptopodia and apoptotic bodies, respectively. Magnification, x200; scale bar, $25 \mu \mathrm{m}$. the pacific yew tree Taxus brevifolia) $(4,5)$ Among natural products, bee products are considered to have numerous pharmacological effects, such as antimicrobial, antiviral, anti-inflammatory and anticancer $(6,7,9)$. The unique characteristics of these products are mostly affected by the species of the bee and geographical factors, as well as the harvesting time $(8,10)$. Therefore, understanding the specific characteristics and pharmacological effects of bee products from each region is essential.

During the initial study, it was revealed that the ethanolic extract and water-insoluble propolis (wax fraction) had a strong cytotoxic activity on MCF-7 cells, with $\mathrm{IC}_{50}$ values of $0.2 \pm 0.09$ and $0.04 \pm 0.003 \mathrm{mg} / \mathrm{ml}$, respectively; these in vitro activities were higher than that using the water-soluble propolis, which had an $\mathrm{IC}_{50}$ of $10.8 \pm 0.06 \mathrm{mg} / \mathrm{ml}(\mathrm{P}<0.05$; data not shown). However, considering that the water-insoluble propolis (wax fraction) contain resinous substances, which are practically insoluble in water and spontaneously form coagulation in an aqueous environment, this could hamper the ethanolic extract and wax fraction to be further developed in the future. Therefore, the water-soluble phase of the extract was further investigated in the present study, in order to elaborate the potency of water-soluble bioactive materials in propolis which have polar or moderate polarity characteristics. It was expected that the bioactive materials in water-soluble propolis and bee pollen would fulfil class 1 (the bioactive materials have high solubility and extensive metabolism) or class 2 (the bioactive materials have low solubility, 
extensive metabolism) criteria of the Biopharmaceutical Drug Disposition and Classification System $(17,18)$. Bioactive materials with class 1 or class 2 characteristics are considered as promising candidates in drug discovery and could be investigated in further research, since they have good solubility and permeability in the gastrointestinal membrane in oral administration $(17,18)$.

Among the products examined, bee pollen had a high antioxidant activity with $\mathrm{EC}_{50}$ against $\mathrm{DPPH}$ radicals of $0.4 \pm 0.06 \mathrm{mg} / \mathrm{ml}$. This value is one-fourth that of vitamin $\mathrm{C}$ and is considered as having mild antioxidant activity (19). Additionally, the water-soluble propolis had lower antioxidant properties than bee pollen, with $\mathrm{EC}_{50}$ of $1.3 \pm 0.4 \mathrm{mg} / \mathrm{ml}$. Furthermore, honey was found to have a low antioxidant properties of $\mathrm{EC}_{50} 6.2 \pm 0.6 \mathrm{mg} / \mathrm{ml}$.

To date, 500 compounds have been identified in propolis (13). Flavonoid content is commonly found in poplar propolis, which is produced in Europe, North America and non-tropical regions of Asia, while the Brazilian propolis, known as the Baccharis type, is abundant in cinnamic acid derivatives (13). CAPE is known as the bioactive compound found in New Zealand, Brazilian and Romanian propolis; this natural phenolic compound is an ester of caffeic acid, which is a hydroxycinnamic acid and phenethyl alcohol $(13,20)$. Using an HPLC-UV detector, the present study revealed that CAPE was not the main bioactive compound in Trigona spp. bee pollen, water-soluble propolis and honey. CAPE was identified in trace values in raw propolis, as well as in water-soluble propolis, estimated as $2 \mathrm{ppb}$. However, due to the below detection limit of HPLC, the present results should be confirmed using more specific LC-MS instruments. The preliminary results using ESI-MS indicated that the spectrum of CAPE was identified as weak in bee pollen. Several intensive spectrums indicated that other compounds may serve a role in the antiproliferative activity of water-soluble propolis and bee pollen from the Trigona spp. SDS-PAGE was used to identify protein constituents in samples. Two primary water-soluble proteins were identified in bee pollen and water-soluble propolis between 50 and $75 \mathrm{kDa}$. These proteins were not identified in honey, wax propolis or the commercial bee pollen powder. However, the specific proteins remain unknown.

In contrast to manuka honey derived from the UK, which has been reported to induce apoptosis at a concentration of $4.7 \%$ (w/v) in MCF-7 cells, and Tualang honey from Malaysia, which also induced apoptosis in a breast cancer animal model, our experimental results revealed that honey from the Trigona spp. examined had no anticancer properties in MCF-7 cells $(10,21)$.

Flow cytometric analysis of the MCF-7 cell line treated for $24 \mathrm{~h}$ with water-soluble propolis and bee pollen at their $\mathrm{IC}_{50}$ concentrations revealed the highest distribution cell population in Annexin V and PI areas. This condition explained that there were changes in cells physiology due to treatments, which may lead to apoptosis. At early apoptosis stage, the cells lose the plasma membrane asymmetry and externalisation of phosphatidylserine to outer membrane occurs. This allows cells to be labeled with Annexin V. The translocation of phosphatidylserine results in loss of membrane cell integrity, which allows PI to enter cells and bind to DNA $(22,23)$. This stage is known as the late apoptosis of the cell. The result was confirmed by cell morphological observation using an inverted phase contrast microscope. The MCF-7 cell line has been originally isolated from breast tissue of a 69-year old Caucasian woman with metastatic disease $(24,25)$. The characterised cells display ER and PR expression, which may represent the luminal A type of breast cancer, which occurs in $80 \%$ of patients with breast cancer $(3,24)$. The untreated MCF-7 cells incubated for $24 \mathrm{~h}$ exhibited normal, healthy and confluent cells, with a cobblestone-like phenotype, a size of 25-30 $\mu \mathrm{m}$ and strong cell-cell adhesion (26). On the other hand, MCF-7 cells treated with bee pollen and water-soluble propolis exhibited a marked morphological change in the apoptotic cells. Characteristics of apoptotic cell morphology include chromatin condensation and cell shrinking, the formation of rounded cells, plasma membrane blebbing and disintegration of organelles, the collapse of the nucleus and organelles, membrane protrusion formation into apoptopodia and the formation of cell fragmentation of apoptotic bodies $(27,28)$. In the present study, treatment with water-soluble propolis for $24 \mathrm{~h}$ induced typical changes of cells in late apoptosis, such as membrane blebbing, formation of apoptopodia and apoptotic bodies, while treatment with bee pollen for $24 \mathrm{~h}$ resulted in the shrinkage of cells to form rounded cells. Furthermore, water-soluble propolis and bee pollen treatment resulted in a decrease in cell density. The population doubling time of MCF-7 cells is $38 \mathrm{~h} \mathrm{(15).}$ Since the significant activity of water-soluble propolis and bee pollen to induce apoptosis was observed within $24 \mathrm{~h}$, this indicated that water-soluble propolis and bee pollen may have a cytotoxic effect in MCF-7 cells. In the future, further study to investigate the mechanism of action of water-soluble propolis and bee pollen which contains of polar bioactive material will be important to understand the potency of these natural products as anticancer therapy.

The water-soluble propolis and bee pollen exhibited similar antiproliferative activities in the MCF-7 cell line; however, these products exhibited markedly different toxicity in HaCaT cells. Water-soluble propolis was toxic to $\mathrm{HaCaT}$ cells after $24 \mathrm{~h}$ of treatment and even more after $48 \mathrm{~h}$ of treatment. Notably, bee pollen resulted less toxic to the cells than water-soluble propolis, with an $\mathrm{IC}_{50}>50 \mathrm{mg} / \mathrm{ml}$ after $24 \mathrm{~h}$ of treatment. A longer treatment for $48 \mathrm{~h}$ revealed that the antiproliferative activity of bee pollen was dose- and time-dependent. The antiproliferative activity of bee pollen was not observed after 24 and $48 \mathrm{~h}$ of treatment with $\leq 3.1 \mathrm{mg} / \mathrm{ml}$. Notably, this activity was observed after $48 \mathrm{~h}$ of treatment, with an $\mathrm{IC}_{50}$ of $9.6 \pm 0.07 \mathrm{mg} / \mathrm{ml}$. The current findings could be a preliminary step for future investigation of bioactive compounds in water-soluble propolis and bee pollen for the development of breast anticancer drugs.

This study presented some limitations. Firstly, the ESI-MS analysis was not completed with reference standard analysis or library compounds information. Therefore, we were not able to identify the presence of the estimated compounds in water-soluble propolis or bee pollen. Secondly, the proteins present in water-soluble propolis and bee pollen are still unknown. Thirdly, current flow cytometric analysis was performed $24 \mathrm{~h}$ after treatment at the $\mathrm{IC}_{50}$ concentration of water-soluble propolis, where majority of the cell $(89.9 \%)$ is already in the late apoptosis stage. Therefore, shorter analysis treatment ( 6 or $12 \mathrm{~h}$ after treatment) could be performed to obtain the profile of the apoptosis stage. Forthly, the in vitro antiproliferative assay in MCF-7 cells of water-soluble propolis 
and bee pollen were conducted at different concentrations. Therefore, the comparison of significant difference at each concentration of samples could not be analysed.

In conclusion, water-soluble propolis and bee pollen of the Trigona spp. from the district of Luwu Utara (South Sulawesi, Indonesia) demonstrated antioxidant and antiproliferative properties against MCF-7 cell proliferation. The antiproliferative activity was observed using a cytotoxic analysis method after treatment for $24 \mathrm{~h}$, and the cytotoxic activity was identified as an apoptosis mechanism. However, the bee products exerted a different toxicity activity in the normal $\mathrm{HaCaT}$ cell line, in which the water-soluble propolis resulted toxic, but the bee pollen resulted less toxic. In contrast to propolis products from other countries, CAPE was not the main bioactive compound. The present results suggested that water-soluble propolis and bee pollen may have the potential to be elaborated further as a breast anticancer therapy. Further research is required to understand the bioactive compounds in water-soluble propolis and bee pollen, and their potential mechanisms of action as a breast anticancer therapy.

\section{Acknowledgements}

The authors would like to thank Dr Ahmad Faried and the Cell Culture and Cytogenetic Laboratory of the Faculty of Medicine of Padjadjaran University (Bandung,West Java, Indonesia) for providing the MCF-7 and HaCaT cell lines.

\section{Funding}

The present study was supported by the Ministry of Research, Technology \& Higher Education, directorate general of research and development strengthening (Indonesia; grant no. 1123s/UN6.O/LT/2019).

\section{Availability of data and materials}

The datasets used and/or analysed during the current study are available from the corresponding author on reasonable request.

\section{Authors' contributions}

EA performed the extracts preparation, antioxidant activity, HPLC and ESI-MS analysis, protein identification, apoptosis/flow cytometric analysis and the in vitro assays. AD and AS evaluated the data, conceived the study and directed the work. EA wrote the manuscript with comments from all authors. All authors read and approved the final manuscript.

\section{Ethics approval and consent to participate}

Not applicable.

\section{Patient consent for publication}

Not applicable.

\section{Competing interests}

The authors declare that they have no competing interests.

\section{References}

1. WHO:BreastcancerWHO,2019.[Online]. Available:https://www. who.int/cancer/prevention/diagnosis-screening/breast-cancer/en/. Accessed Dec 15, 2019.

2. Shah R, Rosso K, and Nathanson SD: Pathogenesis, prevention, diagnosis and treatment of breast cancer. World J Clin Oncol 5: 283-298, 2014.

3. Amalia E, Diantini1 A and Subarnas A: Overview of current and future targets of breast cancer medicines. J Pharm Sci Res 11: 2385-2397, 2019.

4. Siddiqui AA, Iram F, Siddiqui S and Sahu K: Role of natural products in drug discovery process. Int J Drug Dev Res 6: 172-204, 2016.

5. Lichota A and Gwozdzinski K: Anticancer activity of natural compounds from plant and marine environment. Int $\mathbf{J}$ Mol Sci 19: 3533, 2018.

6. Choudhari MK, Haghniaz R, Rajwade JM and Paknikar KM: Anticancer activity of Indian stingless bee propolis: An in vitro study. Evid Based Complement Alternat Med 2013: 928280, 2013.

7. Omene C, Kalac M, Wu J, Marchi E, Frenkel K and O'Connor OA: Propolis and its active component, caffeic acid phenethyl ester (CAPE), modulate breast cancer therapeutic targets via an epigenetically mediated mechanism of action. J Cancer Sci Ther 5: 334-342, 2013.

8. Kustiawan PM, Puthong S, Arung ET and Chanchao C: In vitro cytotoxicity of Indonesian stingless bee products against human cancer cell lines. Asian Pac J Trop Biomed 4: 549-556, 2014.

9. Mărghitas LA, Dezmirean D, Drâglă F and Bobis O: Caffeic acid phenethyl ester (CAPE ) in Romanian propolis. Bull UASVM Anim Sci Biotechnol 71: 111-114, 2014.

10. Portokalakis I, Mohd Yusof HI, Ghanotakis DF, Nigam PS and Owusu-Apenten RK: Manuka honey-induced cytotoxicity against MCF7 breast cancer cells is correlated to total phenol content and antioxidant power. J Adv Biol Biotechnol 8: 1-10, 2016.

11. Mahani, Nurhadi B, Subroto E and Herudiyanto M: Bee propolis Trigona spp. potential and uniqueness in Indonesia. Proc Univ Malaysia Teren Annu Sci 2011, 2011.

12. Riswahyuli Y, Rohman A, Setyabudi FMCS and Raharjo S: Indonesian wild honey authenticity analysis using attenuated total reflectance-fourier transform infrared (ATR-FTIR) spectroscopy combined with multivariate statistical techniques. Heliyon 6: e03662, 2020.

13. Kitamura $\mathrm{H}$ : Effects of propolis extract and propolis-derived compounds on obesity and diabetes: Knowledge from cellular and animal models. Molecules 24: 4394, 2019.

14. Murtaza G, Karim S, Akram MR, Khan SA, Azhar S, Mumtaz A and Bin Asad MH: Caffeic acid phenethyl ester and therapeutic potentials. Biomed Res Int 2014: 145342, 2014.

15. American Type Culture Collection: SOP: Thawing, Propagating and Cryopreserving of NCI-PBCF-HTB22 (MCF-7). Version 1.6, 2012.

16. García-Viguera C, Ferreres F and Tomás-Barberán FA: Study of canadian propolis by GC-MS and HPLC. Z Natforsc C 48c: 731-735, 1993.

17. Ji LI, Larregieu CA and Benet LZ: Classification of natural products as sources of drugs according to the biopharmaceutics drug disposition classification system (BDDCS). Chin J Nat Med 14: 888-897, 2016.

18. Tsume Y, Mudie DM, Langguth P, Amidon GE and Amidon GL: The biopharmaceutics classification system: Subclasses for in vivo predictive dissolution (IPD) methodology and IVIVC. Eur J Pharm Sci 57: 152-163, 2014.

19. Irnawati, Purba M, Mujadilah R and Sarmayani: Penetapan kadar vitamin C DAN UJI aktifitas antioksidan sari buah songi (Dillenia serrata Thunb.) terhadap radikal DPPH (Diphenylpicrylhydrazyl). Pharmacon 6: 40-44, 2017 (In Indonesian).

20. Bankovaa VS, de Castro SL and Marcucci MC: Propolis: Recent advances in chemistry and plant origin. Apidologie 31: 3-15, 2000.

21. Ahmed S and Othman NH: The anti-cancer effects of Tualang honey in modulating breast carcinogenesis: An experimental animal study. BMC Complement Altern Med 17: 208, 2017.

22. Wlodkowic D, Skommer J and Darzynkiewicz Z: Flow cytometery-based apoptosis detection. Methods Mol Biol 559: 19-32, 2009. 
23. Hingorani R, Deng J, Elia J, McIntyre C and Mittar D: Detection of apoptosis using the BD Annexin V FITC assay on the BD FACSVerse ${ }^{\mathrm{TM}}$ system. BD Bioscience application note 2011: 1-12, 2011.

24. Comşa Ş, Cîmpean AM and Raica M: The story of MCF-7 breast cancer cell line: 40 tears of experience in research. Anticancer Res 35: 3147-3154, 2015.

25. Camarillo IG, Xiao F, Madhivanan S, Salameh T, Nichols M Reece LM, Leary JF, Otto KJ, Natarajan A, Ramesh A and Sundararajan R: Low and high voltage electrochemotherapy for breast cancer: An in vitro model study. Electroporation Based Therapies Cancer: 55-102, 2014.

26. Kiosses WB, Hahn KM, Giannelly G and Quaranta V: Characterization of morphological and cytoskeletal changes in MCF10A breast epithelial cells plated on Laminin-5: Comparison with breast cancer cell line MCF7. Cell Commun Adhes 8: 29-44, 2001.
27. Reed JC: Mechanisms of apoptosis. Am J Pathol 157: 1415-1430, 2000.

28. Niknafs B: Induction of apoptosis and non-apoptosis in human breast cancer cell line (MCF-7) by cisplatin and caffeine. Iran Biomed J 15: 130-133, 2011.

cc) (i) (-) This work is licensed under a Creative Commons cc) International (CC BY-NC-ND 4.0) License. 